\title{
Spell checker implementation to analyze the narrative essay of sixth-grade elementary school students in Indonesia
}

\author{
Muhana Gipayana * \\ Department of Elementary and Pre School, Universitas Negeri Malang, Malang, Indonesia \\ gipayana@gmail.com \\ * corresponding author
}

\begin{tabular}{|c|c|}
\hline ARTICLE INFO & ABSTRACT \\
\hline $\begin{array}{l}\text { Article history } \\
\text { Received December 2, } 2016 \\
\text { Revised December 28, } 2016 \\
\text { Accepted January 14, } 2017\end{array}$ & $\begin{array}{l}\text { Learning Bahasa Indonesia correctly in terms of writing and reading is needed by } \\
\text { students to understand well the language learned in school. Some problems arise } \\
\text { when elementary school students still need guidance in writing Indonesian } \\
\text { sentences in narratives, that are still lacking the standard or misspelling. } \\
\text { Teachers usually read essays from students but it takes a lot for the teacher to } \\
\text { learn. This research emerged with the aim of assisting teachers and students in } \\
\text { correcting the spelling of the essay that was written so that it would be a perfect } \\
\text { and perfect sentence. Applications built using internet technology so students } \\
\text { can access the system anywhere. The results show that } 87 \% \text { of students } \\
\text { experience spelling errors in writing narrative essay because they are inaccurate } \\
\text { to what they write, so the application will provide automatic correction and } \\
\text { already implemented in several schools at Malang. }\end{array}$ \\
\hline
\end{tabular}

This is an open access article under the CC-BY-SA license.

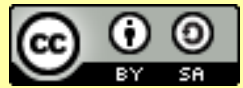

\section{Introduction}

In essence, Indonesian language learning is directed to improve the ability to communicate orally and written Indonesian and to cultivate the appreciation of Indonesian literary works and intellectual works [1]. Learning Indonesian in elementary school has an important value because this is the first time teaching Indonesian language implementation is planned and directed at this level of education. The general objectives of learning Indonesian Elementary School are [2]:

- Students appreciate and pride the Indonesian as the language of unity and national language.

- Students understand Indonesian in terms of form, meaning, and function and its appropriate and creative use for various purposes and circumstances.

- Students have the ability to use Indonesian language to improve intellectual ability, emotional maturity, and social maturity.

- Students have discipline in thinking and speaking.

- Students are able to enjoy and utilize literary works to develop a personality, broader life insight and improve knowledge and language skills.

- Students appreciate and boast Indonesian literature as a cultural and intellectual repertoire.

The above can be achieved if Indonesian language teachers in primary schools can teach the Indonesian language efficiently, effectively and directed. The quality of learning development greatly affects student learning outcomes. The methodology of language learning based on communicative approach revealed that game learning method, role play simulation, and partner communication can be applied [3]. 
In order to measure the success of Indonesian language learning in elementary schools in accordance with the intellectual, social, and emotional development of students, it is required minimum qualification standards or minimum mastery standards (SKM) that describes the mastery of knowledge, skills and positive attitudes toward Indonesian language and literature.

Some elementary school students in Malang have many difficulties in studying narrative essay, this is because to give evaluation takes a long time for the teacher to make corrections by reading every sentence. Researchers have coordinated with several elementary schools to provide solutions to these problems, and the solution is to create applications that can help students automatically get feedback from the narrative essay they have written. This feedback is very important and it takes students to develop narrative writing skills by getting better.

\section{Literature Review}

The following description are some basic knowledge that should be known in the implementation of the method.

\subsection{Narrative Essay}

Essays began to be known in the 1500s where a French philosopher, Montaigne, wrote a book that included some anecdotes and observations. His first book was published in 1580 entitled Essais which means attempts or effort. Montaigne wrote several stories in this book and states that his book was published based on his personal opinion. This essay, based on Montaigne's acknowledgment, aimed to express his view of life.

In Indonesia, the form of the essay was popularized by HB Jassin through his reviews of Indonesian literary works which were then recorded (four volumes) under the title Modern Indonesian Literature in Criticism and Essay (1985), but Jassin could not explain the essay formulation.

An essay is a brief prose composition expressing the author's opinion on a particular subject. A basic essay is divided into three parts: an introduction that contains background information that identifies the subject and the introduction of the subject; body of essays presenting all information about the subject; and the last is the conclusion that gives the conclusion by recalling the main idea, the summary of the body of the essay, or adding some observations about the subject.

What distinguishes essays and others? Answering this question can be done by referring existing opinions or formulas, but the opinions or formulations that have been there are often still incomplete and sometimes contradictory so it still contains shortcomings as well. For example about the size of the essay, there is a free, medium, and can be read once sitting. About the contents of the essay, there is a statement in the form of analysis, interpretation, and descriptions (literature, culture, philosophy, science). Furthermore, likewise of the essay styles and methods there are those who declare free and there are regular states.

Essay explanations can be more "safe and easy to understand" if taken by borrowing the division of Edward de Bono's model of reasoning. According to De Bono, reasoning can be divided into two models. First, the model of vertical reasoning (focusing and setting aside something irrelevant) and the two models of lateral reasoning (open attention and accept all possibilities and influences).

From the division of this reasoning model, essays tend to apply lateral reasoning because essays tend not to be analytical and random, but can be skipping and provocative. Because, the essay according to its meaning of the word origin is an attempt or experiment that does not have to answer a problem in a final, but rather want to stimulate. According to Francis Bacon, essays are more like salt-generating salt grains than a filling meal.

Describe an idea by way of speaking. The events told are usually presented in the order of time. The persuasive essay tries to alter the reader's behavior or motivate the reader to participate in an action/action. This essay can express an emotion or look emotional. Support details are usually presented in order of importance. The following paragraph is an example of a narrative essay written by one of the primary school students:

Tepat ketika tanggal 10 Maret, sekolahku libur selama sembilan hari dan akan berakhir pada tanggal 18 Maret. Aku dan seluruh keluargaku tidak menyia-nyiakan waktu ini untuk mengadakan liburan keluarga. Ketika itu aku memilih berlibur ke Pantai Parangtritis. Pagi-pagi aku telah 
berbenah dan menyiapkan semua perbekalan yang nantinya diperlukan. Sepanjang perjalanan, aku iringi dengan nyanyian lagu riang. Betapa senangnya aku ketika sampai di pantai tersebut. Dengan hati suka ria, aku sambut Pantai Parangtritis dengan senyumku. Pantai Parangtritis, pantai nan elok yang menjadi favoritku. Tanpa menyia-nyiakan waktu, aku mengajak kakakku untuk bermain air. Kuambil air dan aku ayunkan ke mukanya. Dengan canda tawa, kami saling berbalasan. Puas rasanya, terasa hilang semua kepenatan karena kesibukan tiap harinya. Di sana, aku dan seluruh keluargaku saling berfoto-foto untuk mengabadikan momen yang indah ini. Tak terasa waktu berjamjam telah kuhabiskan disana. Hari pun mulai sore menandakan perpisahan dan kembali pulang. Tak rela rasanya kebahagiaan ini akhirnya selesai. Dalam benakku, aku kan kembali esok.

\subsection{Writing Skills}

Writing skill is one type of language skills that students must master. Many scholars have put forward the notion of writing. In addition, writing skills are the ability to express ideas, opinions, and feelings to others through written language. The accuracy of disclosure of ideas must be supported by the accuracy of the language, vocabulary and grammatical and spelling used. Writing skills is a skill pouring thoughts, ideas, opinions about something, a response to a statement of desire, or the expression of feelings by using the language [4].Writing skills is one of the productive and expressive language skills that are used to communicate indirectly with others [5]. The skill of writing essays or writing is to pour ideas into the written language through the sentences that are strung together and clear so that can be communicated to the reader successfully [6].

Writing is an act of expressing ideas through the language medium [7]. Writing is a productive and expressive activity so the writer must have the ability to use vocabulary, grammar, and language structure. Writing skills as an act of transferring thoughts and feelings into the written language using symbols [8]. Writing skills is defined as the ability to use language to express ideas, thoughts or feelings to others by using written language [4]. Writing is an act of expressing ideas, ideas, thoughts or feelings into the linguistic symbols. Writing is an activity to convey a message (communication) by using written language as a medium or tool [9]. In written communication there are at least four elements involved are (1) the author as messenger, (2) Content of writing or message, (3) channel or media in the form of writing and (4) the reader as the recipient of the message. Writing skills is a skill in making letters, numbers, names, any sign of any language with a stationary on a particular page [10]. While making up is a whole series of one's activities in expressing ideas and passing them through written language to the reader's community to be understood. Based on some opinions above, it can be argued that writing skills are a skill to pour ideas, ideas, and feelings in the form of written language so that others who read can understand the contents of the article well.

\subsection{ADDIE Model Development}

The ADDIE development model is an acronym of Analysis (Analysis), Design (Design), Development (Development), Implementation (Implementation), and Evaluation (Evaluation). The steps of the ADDIE development model are characterized as a generic-systemic approach, which can also be encountered in the field of software engineering and product design. Another feature of this development model is that it is systematic in that the output of the previous process becomes the input for the next process [11].

The model of ADDIE development begins with an analysis of needs, i.e. surveying the scope of development to determine what are the priorities and development goals [11]. The design stage is the stage where the development goal is designed in the form of blueprint (design). At the development stage, the blueprint is then manifested using materials in the form of specific procedures or equipment. At the implementation stage (implementation), procedures or equipment have been prepared and then realized in real terms within the scope of development. The evaluation stage is the stage where the developer evaluates to see the extent to which development is based on a predetermined objective. At this stage, revisions can be made to the things that are deemed necessary. The scheme of the ADDIE development model shown at Figure 1. 


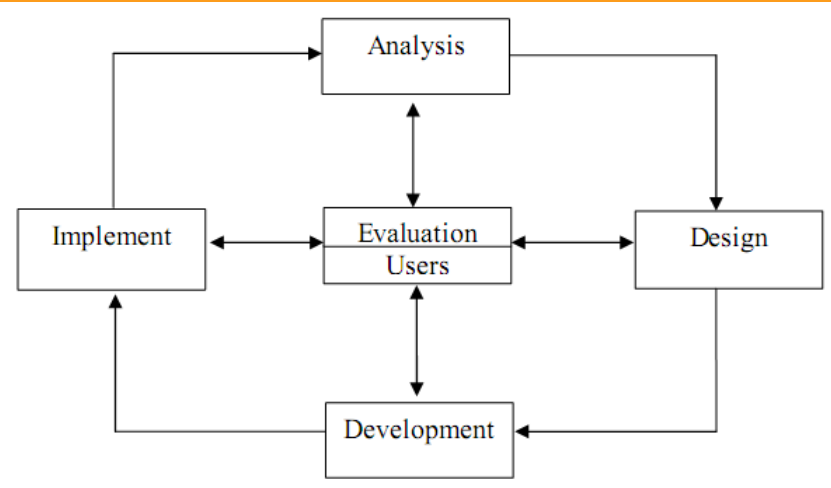

Fig. 1.ADDIE model development.

With generic systemic features and a wide range of fields, the ADDIE development model can be applied as a procedure for developing constructivist learning methods. Theory and learning strategies derived from Instructional System Design (ISD) or Instructional System Design, including the ADDIE model, can be applied in the learning process to help educational practitioners or providers develop the instructional design of optimal learning to motivate learners better in absorbing knowledge, skills, and experience.

Application of the ADDIE development model through constructivist learning approach is expected to create a learning environment that reflects real-world experiences so that it will support teaching and learning activities effectively and efficiently.

\subsection{Spell Correction}

Spell correction is a software intended to correct the mistakes in spelling. Spell correction will help the user in the process of checking the correct words they entered. Of course, there will be words that are considered correct or incorrect by the spell correction software. The word which is considered to be incorrect will be converted into words that are considered to be correct by the spell correction software. Some applications which have been using spell correction features including a word processor, email client, electronic dictionary and search engine.

Spell checker is the fundamental spelling correction tool. The first spell checker software already existed in the late 1970's mainframe computer. But the spell checker for personal computers has begun to exist in 1980. Then the IBM PC software also included a spell checker in 1981. Seeing the enormous benefit in addition of spell checker facility, the manufacturer of word processing software such as WordPerfect and WordStar include spell checker feature in their software. In addition to winning the market as a strategy to reap the benefits, besides of English spelling, the producer also made supports for other languages such as Hungarian and France languages, and also Asian countries. With varying amounts of training data, vocabulary size may change with the size of the training set [12]. That experiments on a large number of data sets show that the two take the similar time to learn and are similarly accurate, but Naive Bayes inference is order of faster magnitude [13]. Probabilistic classifiers are often criticized because they do not induce declarative, interpretable models [14]. However, an often overlooked advantage is that the probabilistic model is a ranked rather than a classifier, and thus can be calibrated to improve classification performance. Interpretability is an important issue in data mining application [15]. Naïve Bayes tree segment the data using a univariate decision tree. The Naïve Bayes work best in two cases: completely independent features and functionally dependent features [16].

\section{Method}

This research is to create an application with spell correction facility for learning written essay in Bahasa Indonesia. It is unfortunate if the written sentence doesn't mean as the mistype has occurred. For example is, search engine Google.com, author of a simple adaptation to the process of checking the word. A simple adaptation was outlined by Peter Norvig, a professor who worked on Google labs that discuss how to do the spell correction in its search engine. This method of spell correction is available to be implemented in other application. 
As described above, the output of training data is words and probabilities. It then will be saved in the database and used as the basic material for calculation in spell correction process and give output to the user for their learning in written English.

\subsection{Analysis}

The analysis phase is the basic and necessary step in order to ensure production of quality learning materials. It comprises many analyses, but for the scope of this research, it was needed that the analysis was conducted with four analyses which are users, content, context, and technology.

The first step in this stage is to know the extent to which elementary school students understand in writing the narrative essay which is then continued by benchmarking on some technology services that are able to help learning the essay, especially the narrative one.

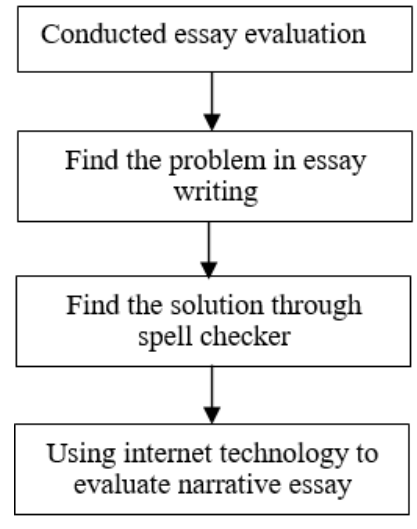

Fig. 2.Step of analysis phase

After the problem arises, then it's important to get the best solution among them. Spell checker is a current optimum solution because it can check written spelling by the students.

\subsection{Design}

The design phase defines the instructional strategies for courses and gives a description of the content like a blueprint. It shows how the content should be organized (learning object approach), presented and delivered to learners, it includes also types of activities and exercises. Some of the issues to be considered when devising an instructional strategy are material grouping and sequencing, instructional methods and tactics (pedagogy) to be used to present materials, learner's assessments methods, etc.

Some exercise questions are made gradually by providing a clear level, for example, there are categories of students who are at level 1 to 6 . Level 1 is the lowest level, meaning that the essay writing still has a lot of mistakes, but the students at level 6 already understand the grammar, which means good so this level is the final stage of practicing essay writing.

The instructional instruction in sequence is also explained through the exposure of teachers in the classroom along with the learning methods that support the development of this system to improve writing skills for elementary school students.

\subsection{Development}

A successful development phase draws upon information collected in the analysis phase and the decisions made in the instructional design phase. Using this information, the prototype can be created and course material developed. The development phase will result into consistency subject materials with sound instructional design principles, technological and pedagogical strategies.

The system development life cycle framework provides a sequence of activities for system designers and developers to follow. It consists of a set of steps or phases in which each phase of the SDLC uses the results of the previous one. The SDLC adheres to important phases that are essential for developers, such as planning, analysis, design, and implementation, and are explained in the section below. It includes evaluation of the present system, information gathering, and feasibility study and request approval. A number of SDLC models have been created: waterfall, fountain, spiral, build, and fix, rapid prototyping, incremental, and synchronize and stabilize. The oldest of these, and the 
best known is the waterfall model: a sequence of stages in which the output of each stage becomes the input for the next process. These stages can be characterized and divided up in different ways, including the following nine processes:

The objective of phase 1 is to conduct a preliminary analysis, propose alternative solutions, describe costs and benefits and submit a preliminary plan with recommendations. In this step, we need to find out the organization's objectives and the nature and scope of the problem under study. Even if a problem refers only to a small segment of the organization itself then we need to find out what the objectives of the organization itself are. Then we need to see how the problem being studied fits in with them. In digging into the organization's objectives and specific problems, we may have already covered some solutions. Alternate proposals may come from interviewing employees, clients, suppliers, and/or consultants. We can also study what competitors are doing. With this data, we will have three choices: leave the system as is, improve it, or develop a new system. The last step is describe the costs and benefits.

The second process is requirements definition. It defines project goals into defined functions and operation of the intended application. Analyzes end-user information needs. The third process describes desired features and operations in detail, including screen lawets, business rules, process diagrams, pseudocode and other documentation. The next process is writing the real code. The fifth process, brings all the pieces together into a special testing environment, then checks for errors, bugs, and interoperability. The sixth process is acceptance, installation, and deployment. Here, The final stage of initial development, where the software is put into production and runs actual business.

The seventh process is maintenance, during the maintenance stage of the SDLC, the system is assessed to ensure it does not become obsolete. This is also where changes are made to initial software. It involves continuous evaluation of the system in terms of its performance. After the maintenance process is evaluation. Some companies do not view this as an official stage of the SDLC, but is it an important part of the life cycle. Evaluation step is an extension of the Maintenance stage and may be referred to in some circles as Post-implementation Review. This is where the system that was developed, as well as the entire process, is evaluated. Some of the questions that need to be answered include: Does the newly implemented system meet the initial business requirements and objectives? Is the system reliable and fault-tolerant? Does the system function according to the approved functional requirements?. In addition to evaluating the software that was released, it is important to assess the effectiveness of the development process. If there are any aspects of the entire process, or certain stages, that management is not satisfied with, this is the time to improve. Evaluation and assessment is a difficult issue. However, the company must reflect on the process and address weaknesses. The final phase are developed for discarding system information, hardware, and software in making the transition to a new system. The purpose here is to properly move, archive, discard or destroy information, hardware, and software that is being replaced, in a matter that prevents any possibility of unauthorized disclosure of sensitive data. The disposal activities ensure proper migration to a new system. Particular emphasis is given to proper preservation and archival of data processed by the previous system. All of this should be done in accordance with the organization's security requirements.

\subsection{Implementation}

The implementation phase, in this case, will involve testing a developed prototype in the pilot site. The test must check for content pedagogical design, accessibility and delivery issues, also test the functions of the content repository.

Storyboard design contains simple lawet design which is more to understand by the student and only focused on the material of e-learning system. Design for students is an important part of this system where students can comfortably follow the distance learning system, students can be created from the comfort of a good application design and in accordance with the wishes of the student as a weng child.

\subsection{Evaluation}

Two types of evaluation are considered in this model, i.e. formative evaluation normally done at each phase and summative evaluation done at the end of all phases. Formative evaluation is preferred for a better quality of the product. Although for the scope of this research only formative evaluation 
will be covered. Evaluation of this system provides information of students writing wrong and correct comparisons so that students can learn to improve the quality of writing independently.

\section{Result and Discussion}

After all, requirement was done, it is the time to see the results of the development application as shown in Figure. This application has been completed in early March 2017 and took one month for students to use and perform on Bahasa essay learning. Students enter the sentence and begin the test of writing skills as shown at Figure 3.

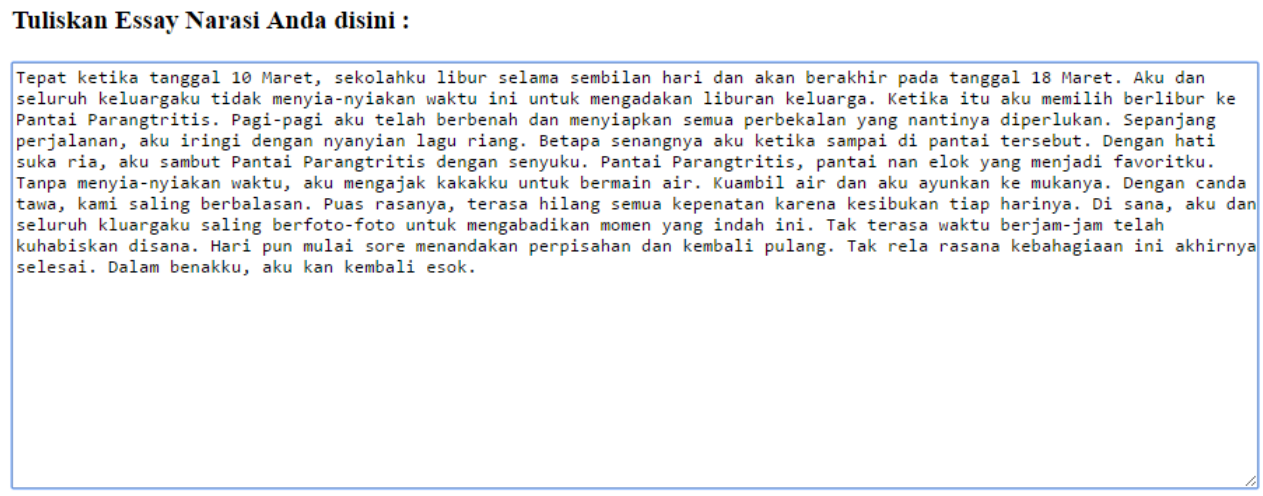

Evaluasi

Fig. 3. Student form input on website.

Students write in the box correctly, then when it is finished, then the "Evaluation" button can be pressed. After that will appear writing evaluation results that shown at Figure 5. The results of this evaluation provide some suggestions for misspelled words, the words "senyuku", "kluargaku", and "rasana". Spell checker application then provides solutions to these problems by displaying the correct results.

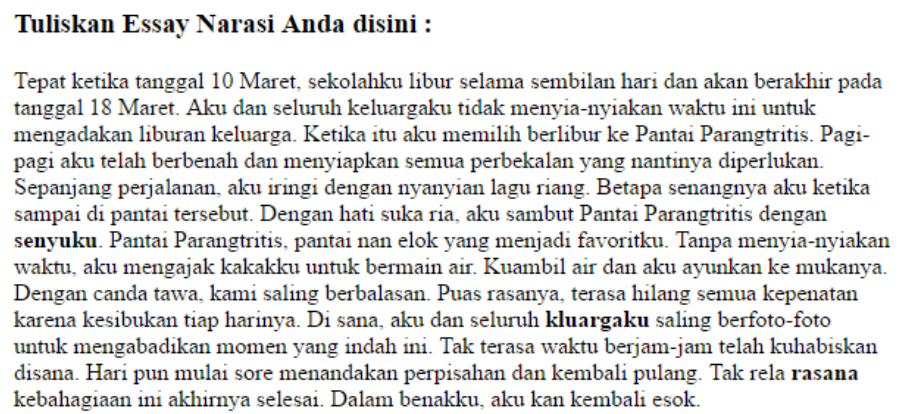

Hasil Evaluasi

kata : senyuku seharusnya senyumku

kata : kluargaku seharusnya keluargaku

kata : rasana seharusnya rasanya

Fig. 4.Evaluation result.

After spell checker application is implemented into 4 schools in Malang as the sample, then the researcher then give questionnaire in the form of questionnaire to the teacher in the school about the responses to the usefulness of this application, whether felt help or even complicate.

The data processing of the questionnaire results stated that $87 \%$ of teachers are satisfied with the results of the application, proved to increase the value of essay narration on average by $30 \%$ from the previous value. This increase in value occurs because students try several times and try not to make the same mistakes. 
The questionnaire results show students satisfaction of $91 \%$ they are happy and feel helped by the application. Students suggest that application design should be attractive and lots of good colors. Teachers at the school also provide suggestions for evaluations other than narrative essays, as students also feel difficulty on other types of essays.

\section{Conclusion}

Based on this research, it can be concluded that the development of media using the ADDIE model has been implemented well in some elementary schools in Malang. Software development is incorporated into Development steps in this model and has resulted in applications that help students in self-evaluation. Students are be able to perform independent learning on narrative essay in order to improve learning outcomes. Students try to visit the website and conduct self-learning activities among peers after that.

\section{Acknowledgment}

I would like to thanks to M Zainal Arifin who helped me to develop the application.

\section{References}

[1] M. Gipayana, Pengajaran Literasi: Fokus Menulis di SD/MI. Malang: Asih Asah Asuh, 2010.

[2] Depdiknas, Kurikulum Berbasis Kompetensi. Jakarta: Puskur Balitbang Depdiknas, 2002.

[3] Tarigan, Pengajaran kosakata. Bandung: Angkasa, 1989.

[4] A. Rofi'uddin and D. Zuhdi, Pendidikan Bahasa Dan Sastra Indonesia di Kelas Tinggi. Jakarta: Depdikbud, 1999.

[5] H. Guntur, Membaca Sebagai Suatu Keterampilan Berbahasa. Bandung: Angkasa, 2008.

[6] Haryadi and Zamzani, Peningkatan Keterampilan Berbahasa Indonesia. Jakarta: Dirjen Dikti, 1997.

[7] B. Nurgiyantoro, Penilaian Dalam Pengajaran Bahasa Dan Sastra. Yogyakarta: BPFE, 2001.

[8] A. Semi, Metode penelitian sastra. Bandung: Angkasa, 1993.

[9] Suparno and M. Yunus, Keterampilan Dasar Menulis. Jakarta: Universitas Terbuka, 2006.

[10]T. L. Gie, Terampil mengarang. Yogyakarta: Andi, 2002.

[11] M. Molenda, "In search of the elusive ADDIE model," Perform. Improv., vol. 42, no. 5, pp. 34-36, 2003.

[12] A. McCallum and K. Nigam, "A comparison of event models for naive bayes text classification," AAAI98 Work. Learn. text Categ., vol. 752, no. 1, pp. 41-48, 1998.

[13]D. Lowd and P. Domingos, "Naive Bayes models for probability estimation," in Proceedings of the 22nd international conference on Machine learning, 2005, pp. 529-536.

[14]P. A. Flach and N. Lachiche, "Naive Bayesian classification of structured data," Mach. Learn., vol. 57, no. 3, pp. 233-269, 2004

[15]R. Kohavi, "Scaling up the accuracy of Naive-Bayes classifiers: a decision-tree hybrid," $K D D$, vol. 96, pp. 202-207, 1996.

[16] I. Rish, "An empirical study of the naive Bayes classifier," in IJCAI 2001 workshop on empirical methods in artificial intelligence, 2001, pp. 41-46. 